\title{
Experimental protein-energy malnutrition in baby baboons
}

\author{
2.* Liver pathology
}

\author{
By R. S. PATRICK AND A. M. MACKAY \\ Glasgow University Department of Pathology, Royal Infirmary, \\ Glasgow, $G_{4}$ oSF \\ AND DOROTHY G. COWARD AND R. G. WHITEHEAD \\ Medical Research Council Child Nutrition Unit, PO Box 67r7, \\ Kampala, Uganda
}

(Received 30 fune 1972-Accepted 8 February 1973)

\begin{abstract}
r. Liver biopsies were performed through laparotomy wounds in six baby baboons during the development of a kwashiorkor-like illness induced by low-protein, high-carbohydrate diets similar to those consumed by many East African children. Up to six biopsies have been performed successfully in one animal within a period of I year. This material has been studied by light and electron microscopy.

2. A similar study was carried out in two healthy animals fed on an adequate diet. A description is given of liver ultrastructure in normal baby baboons, based on examination of these biopsies.

3. The hepatocytes of the malnourished animals contained excessive amounts of glycogen and showed a reduction in rough and smooth endoplasmic reticulum. Even at the height of an illness indistinguishable clinically from marasmic kwashiorkor, there was no excess of liver fat except in those animals whose diet contained sucrose. This may have been the result of stimulation of hepatic triglyceride synthesis by fructose.

4. In no specimen from the experimental group were there signs of serious progressive and irreversible liver cell damage which might have been expected if liver dysfunction were an important component of kwashiorkor.

5. Biopsies performed in one malnourished animal during recovery showed a return of liver ultrastructure to normal.
\end{abstract}

Fatty liver is generally regarded as an essential component of kwashiorkor. It may be present in an extreme degree, and this has naturally given rise to speculation regarding the role of hepatic dysfunction and the subsequent development of chronic liver disease in such patients. However, the degree of fatty change may be difficult to correlate with the general severity of the illness (Waterlow \& Weisz, 1956), and clinical and biochemical evidence of impaired liver function is often unimpressive (Smith, 1962).

The present experimental study has been carried out on baby baboons which developed an illness with clinical features of kwashiorkor following the consumption of various low-protein, high-carbohydrate diets similar to those normally eaten by East African children who develop the disease. It was possible to perform liver biopsies on these animals during the course of their illness, from which some assessment of the role of the liver in kwashiorkor has been attempted. As we could find no

* Paper no. I: Br. F. Nutr. (1972), 28, 223. 
record of the ultrastructure of normal baby baboon liver for comparison with our results, we have included a description of the electron-microscopic appearances of material from healthy control animals.

\section{EXPERIMENTAL}

\section{Animals and diets}

Liver histology and ultrastructure were studied in six malnourished baby baboons (numbered $\mathrm{B}_{\mathrm{I}}$ and $\mathrm{B}_{2}, \mathrm{~B}_{4}, \mathrm{~B} 6-\mathrm{B} 8$ ) and in two normal controls $\left(\mathrm{B}_{3}\right.$ and $\mathrm{B}_{5}$ ). All were weaned at $8-10$ weeks of age, and malnutrition was induced by the gradual withdrawal of milk and its substitution with local staples - mainly banana, cassava and pawpaw. $\mathrm{B}_{\mathrm{I}}$ and $\mathrm{B}_{2}$ both developed a kwashiorkor-like illness after 200-300 d on this starchy diet, but only when the daily quantity had been reduced to provide about I g protein and $120-290 \mathrm{~kJ}$ ( $30-70 \mathrm{kcal}$ ) energy $/ \mathrm{kg}$. The gross facial and limb oedema, loss of hair, flaky-paint dermatosis and mental apathy exhibited by these animals together with severe hypoalbuminaemia were characteristic of the human disease. $\mathrm{B}_{4}$ did not show these signs but succumbed eventually to the same illness after further dietary restriction and the introduction of sucrose to provide $20 \%$ of the total energy intake. Because of this, B6, B 7 and B 8 were each given sucrose at an early stage of their dietary regimens and each suffered a more rapid deterioration. Further dietary and clinical details of these same animals have already been reported (Coward \& Whitehead, I972).

\section{Liver biopsy}

Each specimen of liver was obtained through a laparotomy wound rather than by a closed needle biopsy procedure because of the quantity of tissue required for biochemical studies, which will be reported later. All operations were performed between 09.00 and 11.00 hours, food having been withdrawn the previous evening at about I 8.00-20.00 hours. General anaesthesia was induced by the intramuscular injection of Sernylan (Parke, Davis and Company, Hounslow, Middlesex), and in some animals it was augmented for short periods with inhaled diethyl ether. As the skin could only be shaved and cleansed under general anaesthesia, the time between induction and removal of the liver specimen varied from 10 to 20 min. The operation has been performed successfully on as many as six occasions on one animal. Care was taken to avoid areas of scarring in the liver from previous biopsies. There were no serious complications in any animal and malnutrition did not inhibit healing to any noticeable degree.

The relationship of each biopsy to the age of the animal and to the duration of malnutrition is shown in Table $\mathrm{I}$. The first liver biopsy was usually performed early in the period of dietary restriction so that any progressive degenerative change might be more readily apparent in later specimens. In one baboon the study was continued during recovery from malnutrition.

\section{Histological methods}

Liver. Immediately after removal, a small slice of liver $1 \mathrm{~mm}$ thick was placed in ice-cold glutaraldehyde, 25 or $45 \mathrm{~g} / \mathrm{l}$ in cacodylate buffer $(\mathrm{pH} 7 \cdot 4)$, where it was cut 


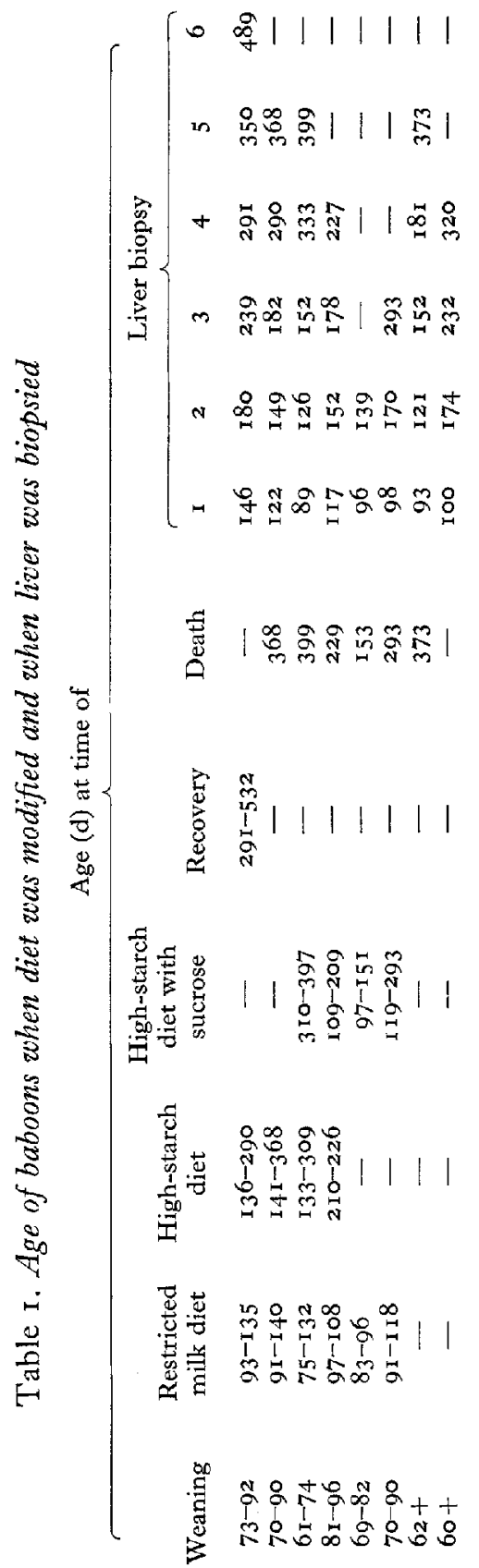


into small blocks about $\mathrm{I} \mathrm{mm}^{3}$. These blocks were washed, $\mathrm{I}$ h later, in cacodylate buffer and transferred to Millonig's osmium solution for a similar period. After washing in phosphate buffer at $\mathrm{pH} 7.4$, the blocks were dehydrated and embedded in epoxy resin by standard procedures. Other blocks of liver were prepared concurrently after fixation in Millonig's fluid alone. From the examination of $0.5 \mu \mathrm{m}$ sections stained with thionin, the epoxy-resin blocks were trimmed to include only the mid-zonal region of the hepatic lobule for electron microscopy.

A thicker section of liver was fixed in $10 \%$ formol saline for $24 \mathrm{~h}$ and passed to paraffin wax for subsequent light microscopy.

Other tissues. A full post-mortem examination was carried out on all six animals which died during the course of the investigation. The results of these autopsies and of skin biopsies taken from each laparotomy wound will be reported at a later date.

\section{RESULTS}

\section{Ultrastructure of normal baby baboon liver}

The nine biopsy specimens from the two normal control animals ( $B_{3}$ and $B_{5}$ ) provided a reasonable assessment of normal baboon liver ultrastructure from the $3^{\text {rd }}$ to the $\mathrm{I} 2$ th month of life. The appearances were very similar to those of other experimental mammalian species and to those of young human subjects.

Hepatocytes fixed by the methods described had diameters of approximately ${ }_{1} 5 \mu \mathrm{m}$. Each nucleus had one or more prominent nucleoli and was approximately $6 \mu \mathrm{m}$ in diameter; binucleate cells were not infrequent. Many of the typical electronmicroscopic findings are illustrated in $\mathrm{Pl}$. I. With aldehyde fixation the nuclear chromatin tended to be clumped against the inner nuclear membrane and around the densely stained nucleolus. The nuclear sap contained granular material including portions of condensed chromatin.

Polyribosomes and granular endoplasmic reticulum could be recognized readily in the cytoplasm of all cells. The profiles of these rough-surfaced membranes were somewhat irregular in distribution compared with the closely packed parallel arrays typical of the rodent hepatocyte. Agranular endoplasmic reticulum was also conspicuous especially in the perinuclear zones, and Golgi complexes could be seen in the bile canalicular areas. Mitochondria were numerous and each contained a few dense granules in the matrix; they were mostly oval or spheroidal but some were irregular in shape. Microbodies or peroxisomes were always very scanty. Glycogen in the form of relatively coarse granules varied in quantity between different hepatocytes and was observed occasionally within lysosomes (Pl. 2, fig. 1). Lysosomes were present in small numbers in the vicinity of most bile canaliculi but complex forms or related particles, for example pigment bodies, were found very infrequently. The amount of collagen lying within Disse's space (Pl. 2, fig. 2) seemed to be greater in amount in these baboons than in normal human liver and was much more conspicuous compared with rodent liver. Peri-sinusoidal cells ('fat-storage cells') which lie within Disse's space and in close association with collagen were identified occasionally. A few cytoplasmic lipid droplets were present, especially in all specimens from the second control 
animal $\left(\mathrm{B}_{5}\right)$. These were of a similar size to mitochondria which might partly envelope them (P1. 3, fig. I).

\section{The liver in malnourished baboons fed on a high-starch diet}

Perhaps the most striking feature of the biopsy specimens from animals of this group (B $\mathrm{B}_{\mathrm{I}}$ and $\mathrm{B}_{2}$ ) was the absence of conspicuous or progressive degenerative conditions including fatty change. In the liver of the second experimental animal, fat could hardly be detected at all by light microscopy even in the specimen taken at the height of the kwashiorkor-like illness (P1. 3, fig. 2); it was quite inconspicuous by electron microscopy, being less than that noted in the second control animal. By contrast, the quantity of cytoplasmic glycogen was greatly in excess of normal. Though this might obscure other cytoplasmic structures there did appear to be a reduction in the quantity of free ribosomes and endoplasmic reticulum, and the agranular variety had almost disappeared from many cells. Most hepatocytes did possess some granular endoplasmic reticulum frequently arranged around mitochondria. Degenerative changes such as cisternal dilatation and ribosomal dislocation were not notable features of these organelles. In a few cells lysosomes and related structures were rather conspicuous; in other specimens collagen seemed to be increased. However, the significance and extent of these changes were difficult to assess in the absence of quantitative studies. In one specimen there was apparent condensation of ground substance within Disse's space to form an ill-defined basement membrane for the sinusoidal lining cells (Pl. 4, fig. I). This phenomenon of 'capillarization' of sinusoids (Schaffner \& Popper, I963) was not observed in normal material. No changes of note were found in the nuclei, nucleoli, mitochondria or other cellular components, and there was no evidence of bile retention.

\section{The liver in malnourished baboons fed on a sucrose-containing diet}

This diet was given initially to the third experimental animal $\left(\mathrm{B}_{4}\right)$ after three liver biopsies had been performed. These biopsies had shown changes characteristic of the group given the high-starch diet. Coexistent with the exaggerated physical deterioration and hypoalbuminaemia which followed the introduction of sucrose into the diet, the liver for the first time showed severe fatty change which persisted until death (fourth and fifth biopsies and autopsy). Likewise fatty change was a striking feature of the liver biopsies from the three animals (B6-B 8) given this type of diet from the beginning of the experiment. It could be detected readily by light microscopy (P1. 4, fig. 2) and appeared as numerous lipid droplets measuring up to several $\mu \mathrm{m}$ in diameter in the electron micrographs (Pl. 5). The features of the hepatocytes found in the other malnourished animals were also present in this group, so that many of these cells appeared to be little more than sacs of fat and glycogen (Pl. 6). No other notable degenerative changes were observed and, in particular, the granular endoplasmic reticulum, although reduced in amount, showed no gross structural abnormality. 


\section{The liver during recovery from malnutrition}

This was studied in one animal only (B I), the first of the experimental group which was allowed to recover by feeding on a normal diet after the development of the kwashiorkor-like illness. Biopsies performed at approximately 2 and 7 months after the reintroduction of this diet showed normal liver ultrastructure in both specimens.

\section{DISCUSSION}

The animals used in the study, when given a low-protein, high-carbohydrate diet similar to that consumed by many East African children, developed during the period between weaning and puberty an illness with the classical features of kwashiorkor. We have shown that this illness could become established in the complete absence of fatty liver and with no ultrastructural evidence of serious or irreversible hepatocyte damage.

Of the various factors concerned in the pathogenesis of fatty liver, probably the most important is deficiency of low-density lipoprotein essential for the transport of triglyceride from the organ. In kwashiorkor, serum concentrations of lipoprotein are low (Flores, Pak, Maccioni \& Monckeberg, 1970), and adequate treatment is followed by an increase in plasma triglyceride (Truswell, Hansen, Watson \& Wannenburg, I969). It can be postulated that fatty liver does not develop in marasmus, as lipoprotein synthesis will be maintained through the liberation of amino acids from wasting muscle; during the development of kwashiorkor, on the other hand, the high-carbohydrate intake stimulates insulin production and consequently the diversion of amino acids to the maintenance of muscle protein (Grimble \& Whitehead, I971). Variations in the intensity of hepatic steatosis as reported by Campbell (1956) and by Garrow, Fletcher \& Halliday ( 1965 ) could be an indication, therefore, of the distribution of individual cases in the kwashiorkor-marasmus spectrum. Certainly all our malnourished animals had reduced intake of total energy as well as protein at some stage of the experiments, particularly baboons $\mathrm{B}_{\mathrm{I}}$ and $\mathrm{B} 2$ which had little or no liver fat. On the whole, however, there was no close correlation between total food or energy intake and severity of fatty change, which appeared to be influenced more by quality than by quantity of ingested carbohydrate; whenever sucrose was used in the diet the development of gross fatty liver quickly followed. This was well seen in the third experimental animal (B4), whose first, second, and third biopsy specimens all showed little or no fat. The fourth and fifth biopsy specimens taken after the commencement of sucrose feeding both showed considerable fatty change despite the maintenance of low total food and energy intake.

Baboons fed on a high-sucrose diet have high concentrations of fructose in their portal venous blood (Crossley \& Macdonald, r970). Fructose, compared with glucose, is a more effective stimulus to hepatic triglyceride synthesis in these animals (Coltart \& Crossley, 1970), probably through the more efficient production of $\alpha$-glycerophosphate, the removal of the feedback inhibition of citrate cleavage and other enzymes concerned with fatty acid synthesis, and its antiketogenic effect which promotes 
esterification of fatty acids (Kornacker \& Lowenstein, 1965). This could explain the severe fatty liver condition following feeding with sucrose, especially in animals already deficient in lipoprotein.

From the results of our studies on baboons which did not receive sucrose in their low-protein diet it would appear that the reduction in hepatic granular endoplasmic reticulum, though doubtless of importance in the development of severe hypoalbuminaemia, was insufficient in itself to cause gross fatty liver through lipoprotein deficiency. This quantitative change must be readily reversible, as our first experimental animal recovered rapidly after treatment. The fully established clinical illness could occur without any prominent degenerative change in surviving endoplasmic reticulum or any increase in monomer or dimer forms of polyribosomes - features which have been described in the livers of rodents fed on low-protein or protein-free diets (Svoboda \& Higginson, I964; Enwonwu \& Sreebny, 1970, I971), and in liver biopsy specimens of those subjects with kwashiorkor investigated by Camain, Rouiller $\&$ Supin (1959).

Glycogen was conspicuous in most specimens from our experimental group of animals. From comparison with all the control specimens, and from our experience of normal human and rodent hepatocyte ultrastructure, it is regarded as excessive. However, there was no increase in numbers of glycogen-containing autosomes which might be expected with defective catabolism of normal glycogen or with storage of abnormal glycogen. Hepatic glycogen excess has also been noted in protein-depleted rats (Enwonwu \& Sreebny, I97I) and in malnourished dogs (Ericsson, Orrenius \& Holm, 1966). Analysis of liver-biopsy material from human subjects with kwashiorkor has revealed low levels of glucose-6-phosphatase (EC I.I.I.49) activity which, in conjunction with high-carbohydrate intake, could explain excessive glycogen accumulation (Fletcher, 1966). The marked reduction in agranular endoplasmic reticulum in our material would be in keeping with this reduced enzyme activity.

It is known that hepatocyte components, and especially glycogen, normally exhibit diurnal variation in quantity. All our biopsies were performed between I0.00 and I2.00 hours, when liver glycogen content is normally high (Rohr, Hundstad, Bianchi \& Eckert, I970). It is recognized, however, that phase shifts in diurnal rhythms may be influenced by diet (Fuller \& Diller, 1970), and we plan to investigate the possible significance of this in our future experimental work.

In no biopsy specimen so far examined have we detected any evidence of advanced or irreversible cell damage, such as fragmentation of plasma membranes, nuclear distortions, or prominent autophagocytosis. There are few reports of liver ultrastructure in human kwashiorkor and we have not observed the degenerative changes in mitochondria and Golgi bodies described by Camain et al. (1959) nor the prominence of microvilli and sinusoidal recesses observed by Theron \& Liebenberg (1963). Waterlow $(\mathrm{I} 96 \mathrm{I}-2)$ has described impairment of oxidative phosphorylation in liver biopsy specimens from children with kwashiorkor, but if this was true of our material, it was not reflected in any structural mitochondrial change.

It is generally agreed that kwashiorkor is not a direct cause of hepatic cirrhosis (Higginson, Grobbelaar \& Walker, 1957), and that, when fibrosis is present, it may be 
due to some coexisting hepatic inflammation or cell damage (Bras, Goldblatt \& György, I959). Light microscopy of our biopsy material has revealed no convincing evidence of any increase in hepatic reticulin. Collagen can be found readily in electron micrographs of liver from normal young baboons, but it was rather more prominent in some biopsy specimens from our malnourished animals, in one of whom there also appeared to be an excess of ground substance in Disse's space. Preliminary studies on our animals based on autoradiography and chemical analysis have revealed an exaggerated uptake of labelled sulphate in the livers of the malnourished group, especially along the sinusoidal walls. This change was reversible in the single protein-depleted baboon $\left(\mathrm{B}_{\mathrm{I}}\right)$ studied during its period of rehabilitation. An exaggerated uptake of sulphate into hepatic mucopolysaccharide has been reported in protein-depleted rats (Becker, I97 I). It is clear that the effect of malnutrition on the metabolism of hepatic connective tissue requires further investigation.

It is our opinion that the changes in hepatocyte ultrastructure which we have described are the consequence only of the abnormal diets consumed by our experimental animals. Even at the height of the kwashiorkor-like illness there were no convincing signs of serious or irreversible liver damage, which might have been expected if severe liver dysfunction were contributing to the clinical condition. It would be important in further work to attempt some quantitative assessment of these structural changes.

The pathological aspects of this work have been carried out with the aid of a grant from the Medical Research Council to one of us (R.S.P.).

\section{REFERENCES}

Becker, K. (1971). Klin. Wschr. 49, 558 .

Bras, G., Goldblatt, H. \& György, P. (1959). Br. J. exp. Path. 40, 172.

Camain, R., Rouiller, C. \& Supin, H. (1959). Ann. Anat. path. 4, 220.

Campbell, J. A. H. (1956). Archs Dis. Childh. 31, 310.

Coltart, T. M. \& Crossley, J. N. (1970). Clin. Sci. 38, 427.

Coward, D. G. \& Whitehead, R. G. (1972). Br. F. Nutr. 28, 223.

Crossley, J. N. \& Macdonald, I. (I970). Nutr. Metab. 12, I7I.

Enwonwu, C. O. \& Sreebny, L. M. (1970). Exp. mol. Path. 12, 332.

Enwonwu, C. O. \& Sreebny, L. M. (1971). \%. Nutr. I0I, 501.

Ericsson, J. L. E, Orrenius, S. \& Holm, I. (1966). Exp. mol. Path. 5, 329.

Fletcher, K. (1966). Am. F. clin. Nutr. 19, т70.

Flores, H., Pak, N., Maccioni, A. \& Monckeberg, F. (1970). Br. F. Nutr. 24, 1005.

Fuller, R. W. \& Diller, E. R. (I970). Metabolism 19, 226.

Garrow, J. S., Fletcher, K. \& Halliday, D. (1965). F. clin. Invest. 44, 417.

Grimble, R. F. \& Whitehead, R. G. (I971). Br. F. Nutr. 25, 253.

Higginson, J., Grobbelaar, B. G. \& Walker, A. R. P. (1957). Am. F. Path. 33, 29.

Kornacker, M. S. \& Lowenstein, J. M. (1965). Biochem. $\mathscr{7} .95,832$.

Rohr, H. P., Hundstad, A.-C., Bianchi, L. \& Eckert, H. (1970), Acta anat. 76, I02.

Schaffner, F. \& Popper, H. (1963). Gastroenterology 44, 239.

Smith, C. E. (1962). F. Pediat. 6r, 617.

Svoboda, D. \& Higginson, J. (1964). Am. Y. Path. 45, 353.

Theron, J. J. \& Liebenberg, N. (1963). F. Path. Bact. 86, 109.

Truswell, A. S., Hansen, J. D. L., Watson, C. E. \& Wannenburg, P. (1969). Am. J. clin. Nutr. 22, 568.

Waterlow, J. C. (1961-2). Proc. R, Soc. B 155, 96.

Waterlow, J. C. \& Weisz, T. (1956). F. clin. Invest. 35, 346 


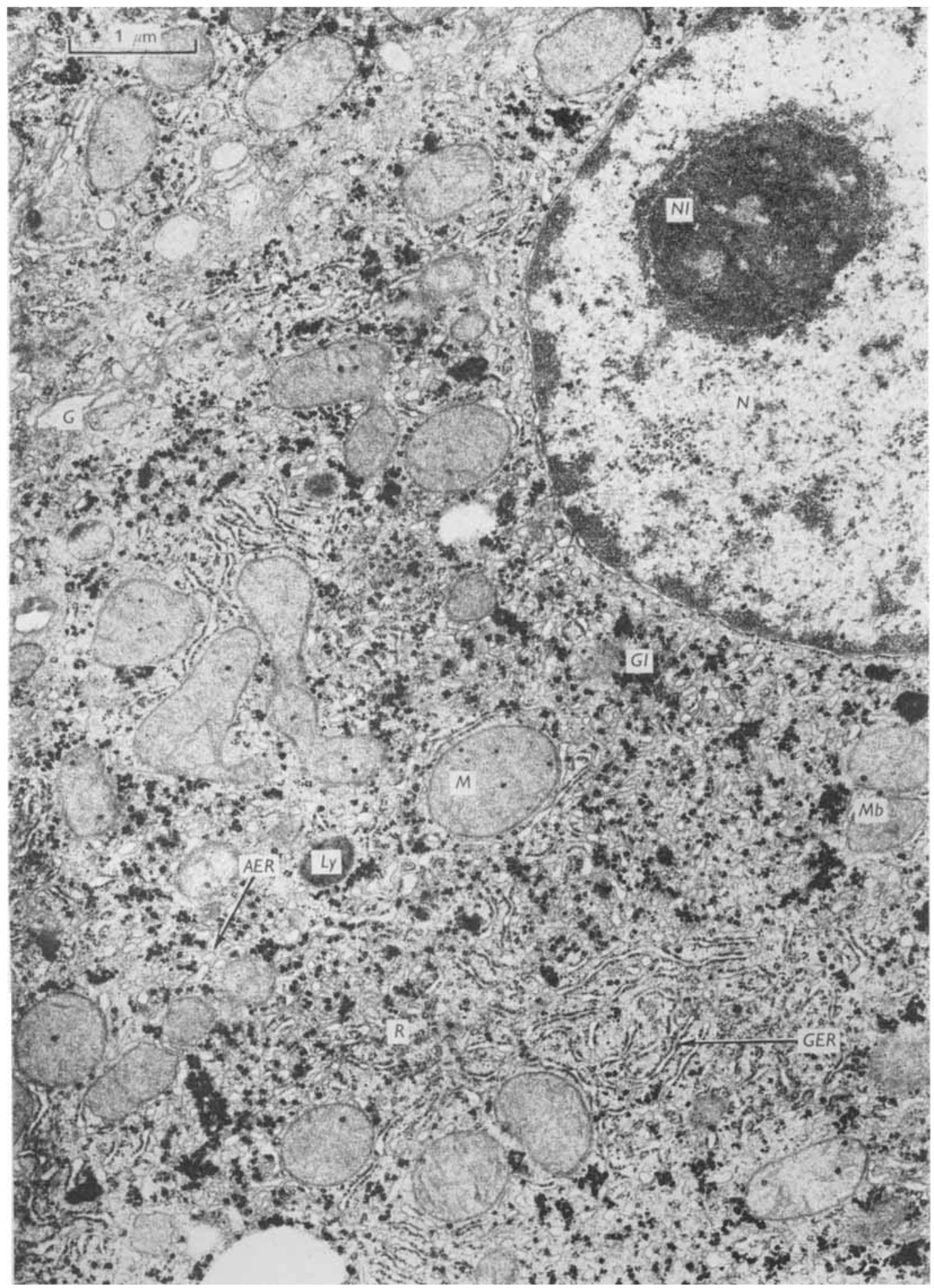



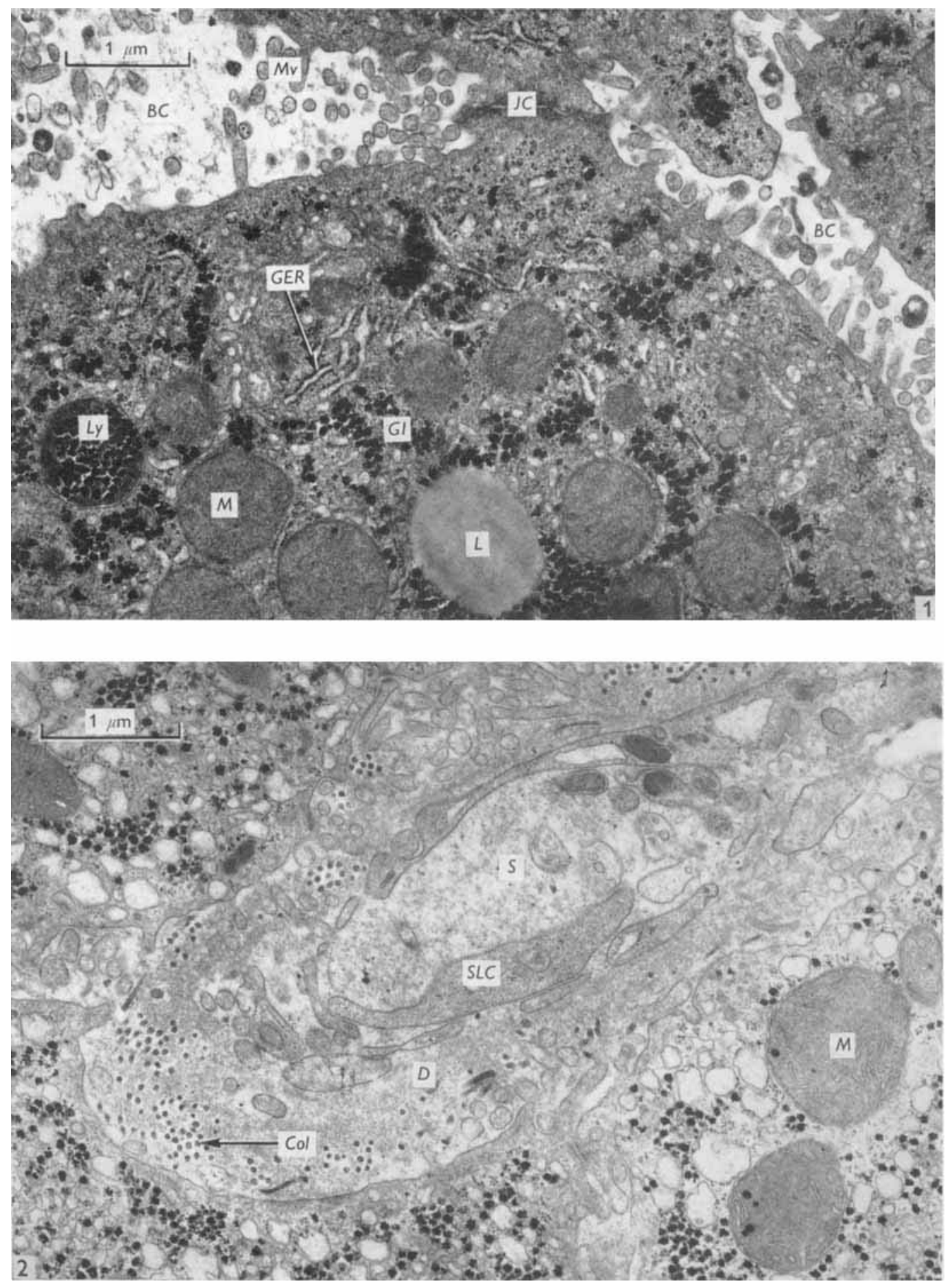

R. S. PATRICK AND OTHERS 


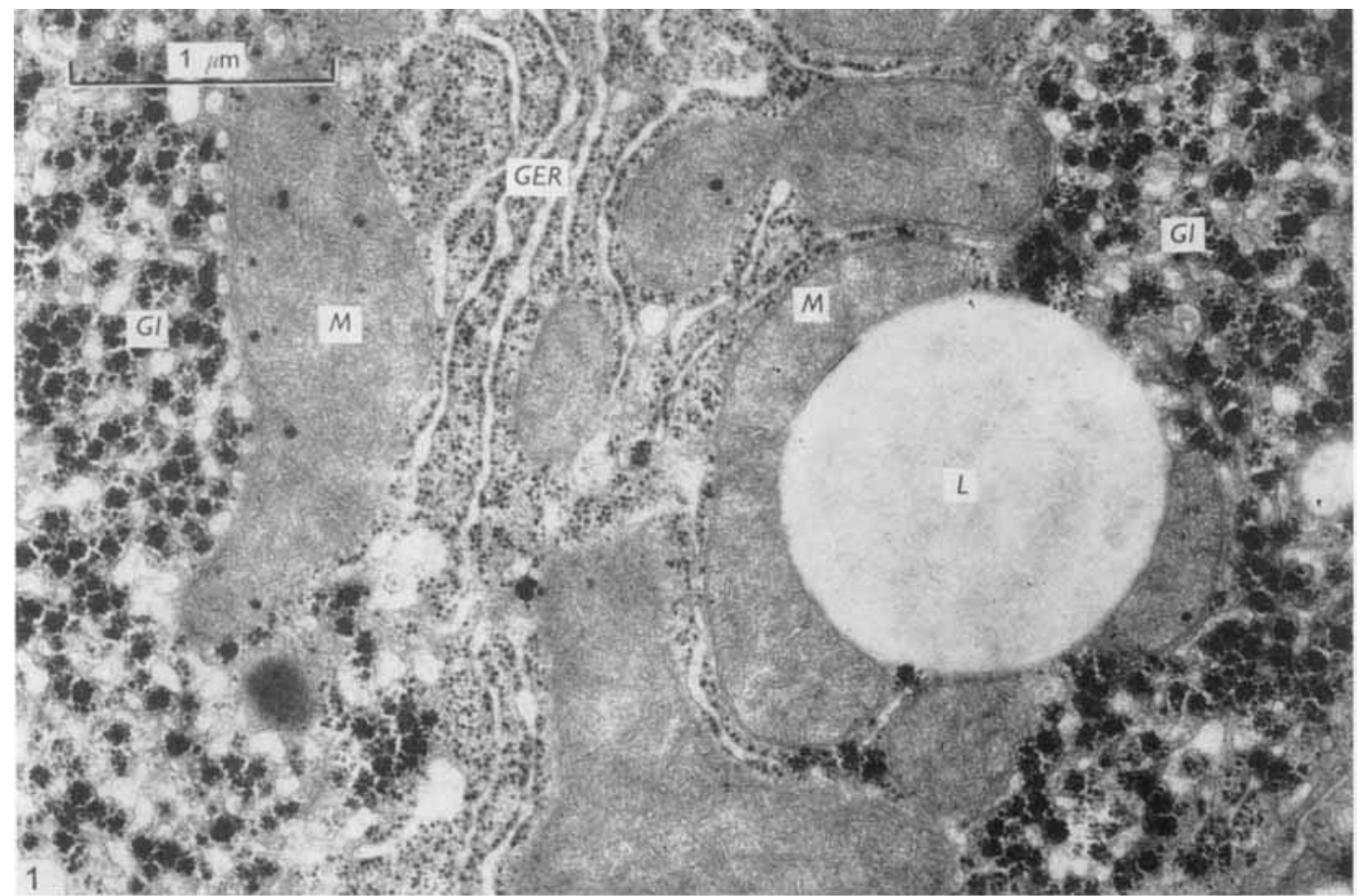

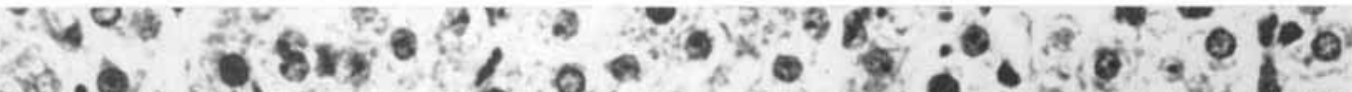

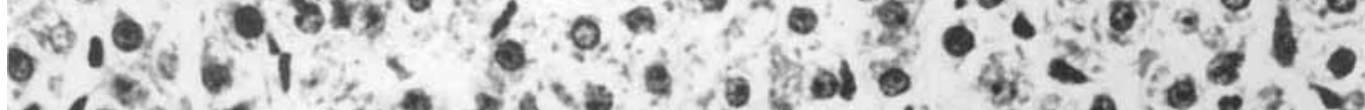

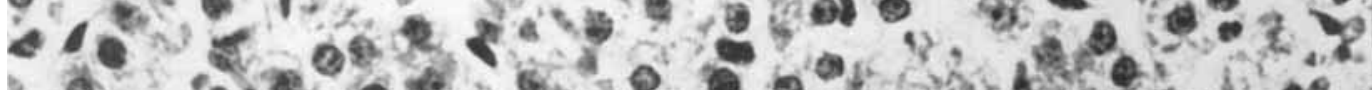

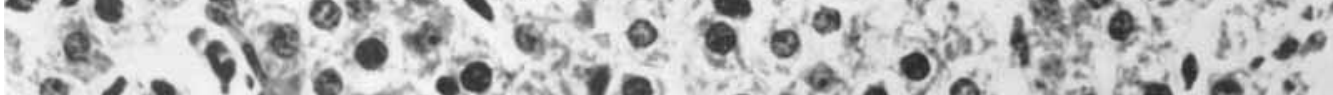
\%

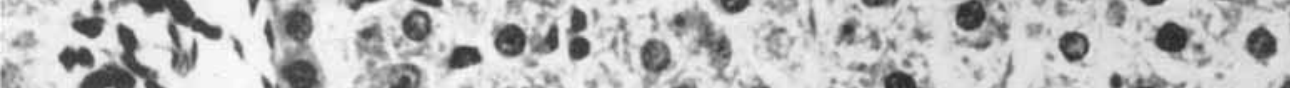

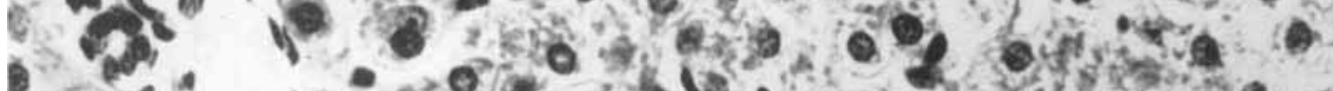
6.

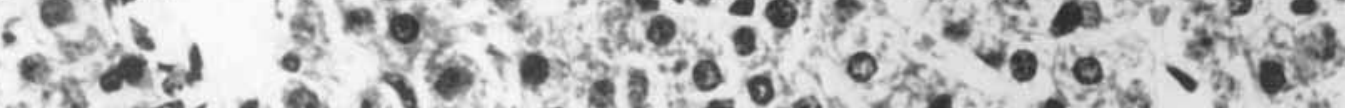

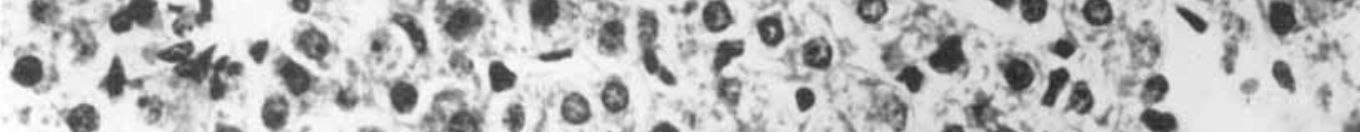

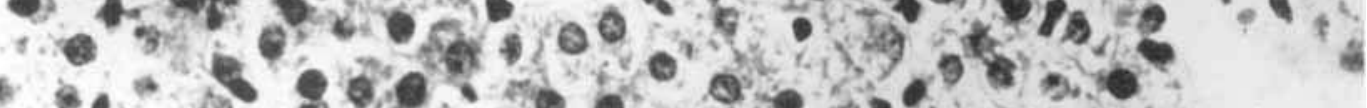

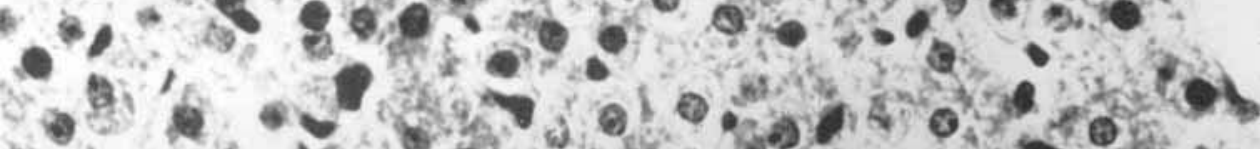

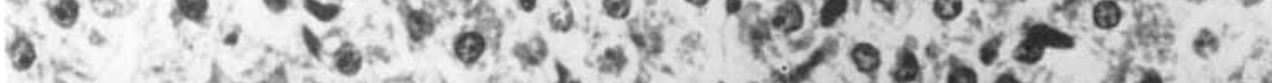

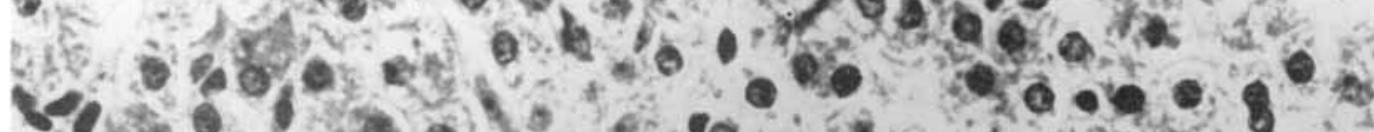

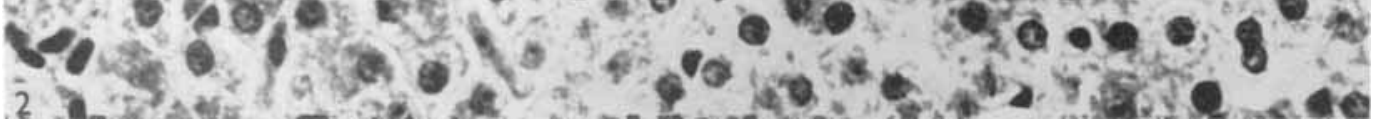

R. S. PATRICK ANI) OTIIIRS 
-

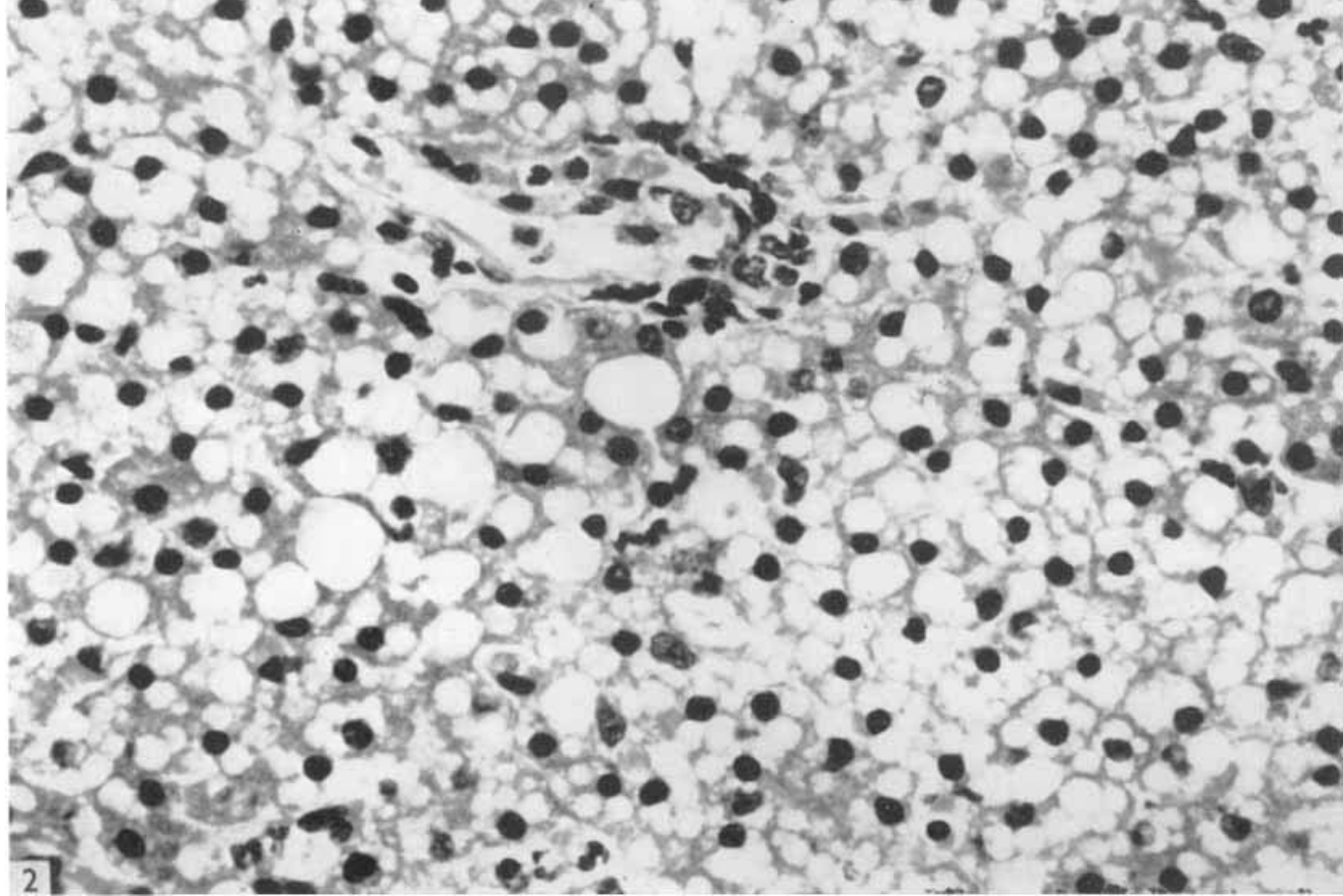

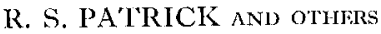


British Fournal of Nutrition, Vol. 30, No. 2

Plate 5

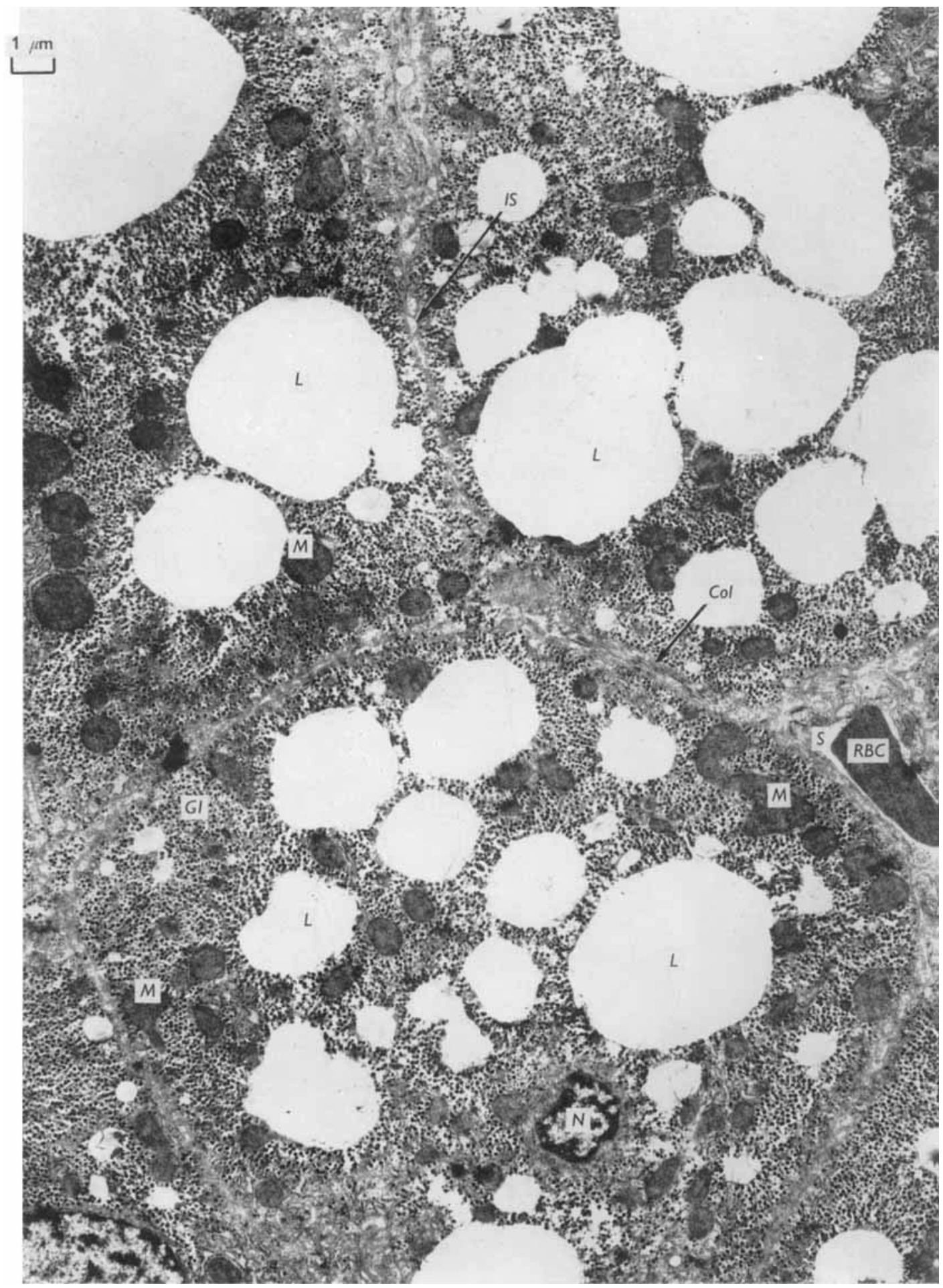

R. S. PATRICK ANI) OHHERS 
British Fournal of Nutrition, Vol. 30 , No. 2

Plate 6

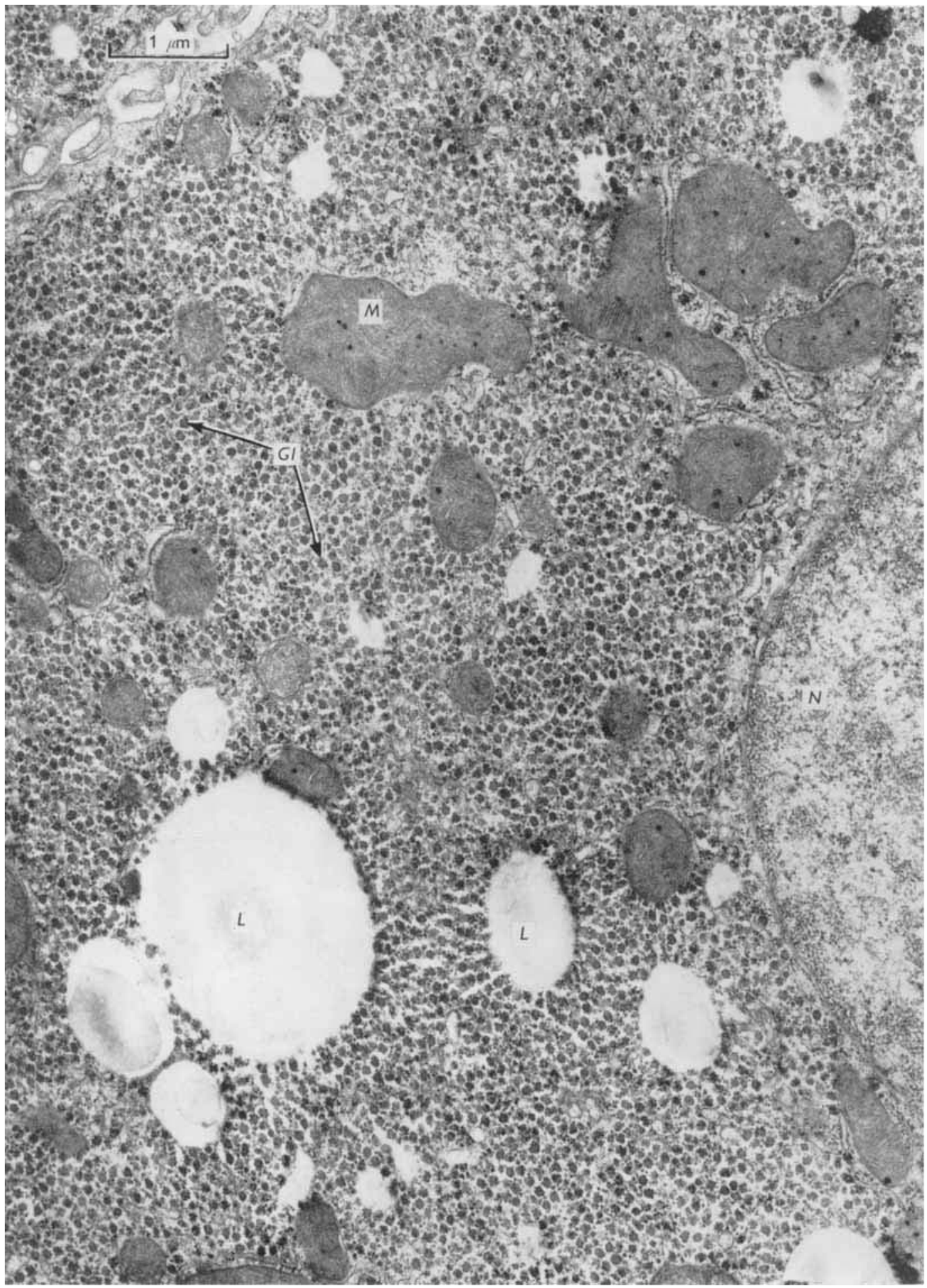

R. S. PAT'RICK AND OTHERS 


\section{EXPLANATION OF PLATES}

\section{Plate I}

Electron micrograph of a normal baboon hepatocyte including a portion of nucleus $(N)$ with its densely stained nucleolus $(\mathrm{Nl})$. The cytoplasm contains numerous ribosomes $(R)$ arranged singly or in clusters, or attached to membranes forming the granular endoplasmic reticulum $(G E R)$. By contrast, the granules and clusters of glycogen $(G l)$ are relatively coarse. Agranular endoplasmic reticulum $(A E R)$ forms numerous small smooth-walled tubules. The more prominent smooth-walled vesicles and channels represent Golgi complexes $(G)$. There are numerous mitochondria $(M)$ each with a double membrane, cristae and finely granular stroma. The microbody $(M b)$ can be distinguished by its single membrane and central nucleoid structure. A dense lysosome $(L y)$ is also present.

\section{Plate 2}

Fig. I. Electron micrograph of normal baboon liver showing bile canaliculi $(B C)$ into which project short microvilli $(M v)$ from adjacent hepatocyte cytoplasm. A junctional complex $(\mathscr{F C})$ or desmosome binds adjacent hepatocytes at the very narrow intercellular space. There is a single lipid droplet $(L)$ and a lysosome $(L y)$ containing ingested glycogen.

Fig. 2. Electron micrograph of normal baboon liver showing a sinusoid $(S)$ lined by fenestrated cytoplasm which is part of a sinusoidal lining cell $(S L C)$. This separates the sinusoid from the space of Disse $(D)$ which contains small microvillous projections of hepatocytes and many collagen fibrils ( $\mathrm{Col})$, most of which are cut transversely.

$$
\text { Plate } 3
$$

Fig. I. Electron micrograph of normal baboon liver showing a lipid droplet $(L)$ partly surrounded by mitochondria $(M)$.

Fig. 2. Liver from baboon with severe kwashiorkor fed on a high-starch diet without sucrose. There is no evidence of fatty change. (Haematoxylin and eosin; magnification $\times 600$.)

\section{Plate 4}

Fig. I. Electron micrograph of the liver of a baboon with kwashiorkor fed on a sucrose-free diet. Within Disse's space $(D)$ there is a line of electron-dense material (arrows) suggestive of basement membrane formation adjacent to sinusoidal lining cell cytoplasm $(S L C)$. The sinusoid $(S)$ contains a red blood corpuscle $(R B C)$.

Fig. 2. Liver of baboon with kwashiorkor fed on a sucrose-containing diet. There is marked fatty change which is most severe in the periportal zone. (Haematoxylin and eosin; magnification $\times 600$.)

\section{Plate 5}

Electron micrograph of liver from a baboon with kwashiokor fed on a sucrose-containing diet. Lipid droplets $(L)$ within hepatocyte cytoplasm are large and numerous. Glycogen $(G l)$ is also conspicuous.

\section{Plate 6}

Electron micrograph of liver from a baboon with kwashiorkor fed on a sucrose-containing diet. The hepatocyte cytoplasmic content consists largely of glycogen $(G l)$ and fat $(L)$. Mitochondria $(M)$ are normal, but endoplasmic reticulum is scanty. 